\title{
Immigration Enforcement and Children's Living Arrangements ${ }^{1}$
}

\begin{abstract}
Tougher immigration enforcement was responsible for 1.8 million deportations between 2009 and 2013 alone - many of them were fathers of American children. We exploit the geographic and temporal variation in the escalation of interior immigration enforcement to assess its impact on the structure of families to which many of the deported fathers of U.S. born children belonged. We find that the average increase in immigration enforcement during the 2005-2015 period has raised the likelihood that Hispanic, U.S. born children might live without their parents in households headed by naturalized relatives or friends unthreatened by deportation by 19 percent. Likewise, the same increase in immigration enforcement has raised these children's propensity to live with likely undocumented mothers who report their spouses as being absent by 20 percent - a reasonable finding given that most children with a likely undocumented father have undocumented mothers. Given the negative consequences of being raised by a single parent or without parents, plus the parallel increase in interior immigration enforcement, gaining a better understanding of the collateral damage of heightened enforcement on the families to which these children belong is well warranted.
\end{abstract}

Keywords: Immigration Enforcement, Undocumented Immigrants, Children's Living Arrangements, Family Structure, United States.

JEL Codes: J13, J15, K37.

\footnotetext{
${ }^{1}$ The authors are grateful for comments received from Katherine Donato, Sankar Mukhopadhyay, Pia Orrenius, Susan Pozo, Bernhard Schmidpeter, Kevin Shih and seminar/conference participants at CUNY Queens College, the Southern California Conference in Applied Microeconomics, the Population Association of American meetings, the IEA World Congress and the Western Economic Association meetings.
} 


\section{Introduction}

Since 9/11, the United States has expanded the number of programs aimed at curbing the number of undocumented immigrants by discouraging their entry and, more importantly, facilitating their apprehension and deportation. Altogether, the various programs were responsible for 1.8 million deportations between 2009 and 2013 (Vaughan, 2013) (Vaughan, 2013) - most of them fathers and heads of households with U.S. born children (Capps et al., 2016)(B. R. Capps et al., 2016). ${ }^{2}$ Despite the increased spending on immigration enforcement and the growing number of removals, many of them non-criminal in nature, the implications of tougher immigration enforcement on immigrant families are yet to be well understood. This is especially true with the changing enforcement priorities under President Trump's Administration, which has resulted in the swift removal of many immigrants who qualified for temporary relief during the prior Administration.

In this study, we aim to assess how the escalation of immigration enforcement taking place at the local and state levels since the early 2000s has impacted the structure of families to which many of the deported fathers of U.S. born children belonged. To that end, we focus on Hispanic U.S. born children. In contrast to their non-citizen counterparts, U.S. born Hispanic children are citizens and, therefore, have the right to stay in the country. The conditions in which these U.S. citizens are raised will play a decisive role on their health, education, development, future employment outcomes and their ability to exhibit good citizenship traits later in life. They will also play a role in the political landscape in future elections. ${ }^{3}$

\footnotetext{
${ }^{2}$ According to the Department of Homeland Security, the term deportation refers to the "formal removal of an alien from the United States when the alien has been found removable for violating the immigration laws," and it is ordered by an immigration judge (see: https://www.uscis.gov/tools/glossary/deportation). For the purpose of this study, we use the terms deportation and removal interchangeably.

${ }^{3}$ In the robustness checks section, we also perform the analysis including non-citizen children. As we shall discuss, the results prove robust to the inclusion of this much smaller and heterogeneous group.
} 
To achieve our aim, we focus on the incidence of two types of living arrangements. First, we assess the role of intensified enforcement on the prevalence of Hispanic U.S. born children living without their parents. Because parental deportations are known to result in children being left behind with relatives or friends not at risk of removal (Capps et al. 2007), gaining a better understanding of the extent to which the current piecemeal approach to immigration enforcement is impacting the likelihood of parentless children seems vital. Secondly, given that many of those deported are married fathers whose spouses remain in the United States (Capps et al., 2016), we subsequently explore how intensified enforcement may have impacted the incidence of children living with mothers who report having an absentee spouse.

Understanding the consequences of intensified immigration enforcement on the structure of families to which many of the deported fathers of U.S. born children belonged is important for a number of reasons. First, an estimated 8 percent of U.S. born children have an undocumented parent -twice as many as in 2002 (see Figure A1). In due course, these children will become eligible voters and have a say on the nation's politics and immigration policy. ${ }^{4}$ Secondly, immigration enforcement has intensified under the current Administration. $^{5}$ Between January 22 and April 29, 2017, Immigration Customs Enforcement (ICE) conducted around 10,800 “non-criminal arrests," compared to just 4,200 in 2016 - an increase of more than 150 percent (U.S. Immigration and Customs Enforcement, 2017a). Additionally, removal priorities have been expanded and enforcement operations targeting individuals without criminal records are now being implemented (Pierce \& Selee, 2017). Lastly, understanding how intensified immigration enforcement is affecting the

\footnotetext{
${ }^{4}$ In 2016, second generation Latinos made up about one-third (32 percent) of Latino eligible voters, up from 27 percent in 2008 and 26 percent in 2000 (see: http://www.pewhispanic.org/2016/01/19/looking-forward-to-2016the-changing-latino-electorate/).

${ }^{5}$ See: http://feixingren.com/news/fact-checker/wp/2017/12/18/the-most-popular-fact-checks-of2017/none?local/immigration-arrests-of-noncriminals-double-under-trump/2017/04/16/98a2f1e2-2096-11e7be2a-3a1fb24d4671_story.html?tid=ss_tw\&utm_term=.ce574d2f8dab
} 
family environment in which an estimated 4.5 million American children grow up is vital given what we know about the importance of the family context early in life on numerous outcomes later on. An established literature on parental incarceration has found that the absence of a parent can strain important protective factors, such as parental involvement, and create risk factors, such as financial hardship (Murray, Farrington, \& Sekol, 2012). Children growing up with one parent or without parents are more likely to drop out the school, experience teen-age pregnancies, and have lower earnings in the future (see for example, Adda, Björklund, \& Holmlund, 2011; McLanahan, 2004). Thus, gaining a better understanding of the impacts of intensified immigration enforcement on the families in which they grow up is well warranted. ${ }^{6}$

Using a unique data set that combines data from the 2005 through 2015 American Community Surveys (ACS) and detailed information on the intensification of immigration enforcement merged at the Metropolitan Statistical Area (MSA) level, we study the impact of immigration enforcement on the structure of families to which many of the deported fathers of U.S. born children belonged. ${ }^{7}$ Specifically, exploiting the temporal and geographic variation of interior immigration policies, we find that the average increase in immigration enforcement during the 2005-2015 period has contributed to raising the likelihood that Hispanic, U.S. born children might live without their parents in households headed by naturalized relatives or friends unthreatened by deportation by 19 percent. Likewise, the same increase in immigration enforcement appears to have raised these children's propensity to live with likely undocumented mothers with absent spouses by 20 percent $-\mathrm{a}$ reasonable finding given that most children with a likely undocumented father have undocumented

\footnotetext{
${ }^{6}$ The 2018 budget for immigration enforcement was 25 percent higher than for the prior year.

${ }^{7}$ U.S. born Hispanic children are the most likely ones to have endured a parental deportation given that 97 percent of individuals deported by ICE originate from Latin American countries (see: http://trac.syr.edu/immigration/reports/350/)
} 
mothers. ${ }^{8}$ We are also able to confirm that the impacts emanate from police-based immigration enforcement policies directly associated to apprehensions and deportations of undocumented migrants, as opposed to employment verification mandates that also have the potential to affect household structure through financial constraints. Finally, the findings prove robust to a number of identification and falsification checks.

Our results contribute to a rapidly growing literature concerned with the consequences of a fragmented approach to immigration enforcement. A number of authors have examined how immigration laws end up shaping the immigrant household by delineating who can enter legally using descriptive or qualitative analyses (see for example; Enchautegui \& Menjivar, 2015). ${ }^{9}$ Additionally, a more recent literature has explored how it has impacted household poverty, the schooling of children, or the civic engagement of its members(AmuedoDorantes, Arenas-Arroyo, \& Sevilla, 2018; Amuedo-Dorantes \& Lopez, 2017, 2015). However, an assessment of how intensified immigration enforcement, as captured by the plurality of local and state level immigration enforcement, has been impacting the structure of families to which many of the deported fathers of U.S. born children belonged is still lacking. In addition, by examining the impact of immigration policies on the families in which 4.5 million children reside, we also contribute to the literature examining the impact of policies on family structure (e.g. Bitler, Gelbach, \& Hoynes, 2006).

The remainder of this paper proceeds as follows. In section 2, we discuss the expected effect of immigration enforcement on children's living arrangements based on the existing literature. We describe the data in Section 3, and our empirical methodology in Section 4. We present our main findings and robustness checks in Section 5, to then assess

\footnotetext{
${ }^{8}$ See Table $\mathrm{C}$ in the Appendix. All appendices are available at the end of this article as it appears in JPAM online. Go to the publisher's website and use the search engine to locate the article at http://onlinelibrary.wiley.com.

9 (Capps et al., 2007) use a small survey on children whose parents were arrested in three worksite raids to provide some descriptive evidence of how deportation of a parent can result in children being left behind in the care of a single parent, an older sibling, or other relatives.
} 
our identification strategy in Section 6. In Section 7, we look closer at the channels through which the observed impacts seem to be taking place, and Section 8 concludes the study.

\section{Immigration Enforcement and Household Composition}

\subsection{Background on Interior Immigration Enforcement}

The 1996 Illegal Reform and Immigration Responsibility Act (IIRIRA) established the framework for the posterior expansion of interior immigration enforcement, including specific employment verification guidelines. Yet, it was not until after the $9 / 11$ attacks that the United States witnessed an unprecedented increase in spending on interior immigration enforcement. As shown in Figure A2, overall spending on immigration enforcement more than quadrupled during that period, as states and smaller localities adopted a growing number of immigration enforcement initiatives under the auspices of the federal law. Some of the aforementioned initiatives focused on verifying work eligibility -as in the case of E-Verify mandates. Because of who is involved in implementing the measures at hand, in this case the employer, we refer to them as employment-based immigration enforcement. Most of the measures, however, effectively delegated immigration enforcement to local and state police. These police-based measures became responsible for the large increase in deportations. They were exemplified by $287(\mathrm{~g})$ agreements between local and state law enforcement with Immigration Customs Enforcement (ICE), as well as by their successor: Secure Communities program. Finally, Omnibus Immigration Laws encompassed employment- and police-based measures. In what follows, we describe the various immigration enforcement initiatives we focus in our analysis -namely, local and state level $287(\mathrm{~g})$ agreements between local and 
state police with Immigration Customs Enforcement (ICE), Secure Communities, Omnibus Immigration Laws and employment verification (E-Verify) mandates. ${ }^{10}$

Active since 2002, 287(g) agreements were one of the earliest police-based immigration enforcement measures. They provided local and state police officers the authority to interrogate any immigrant, arrest without warrant, and begin the removal process -this was the so-called "task force" agreement. In other instances, the agreements allowed police officers to question immigrants who have been arrested about their immigration status -this was the "jail enforcement" agreement. Finally, in many instances, "hybrid" agreements combining many of the traits of "task force" and "jail enforcement" agreements were adopted instead. Between 2006 and 2010, the budget for 287(g) increased from $\$ 5$ million to $\$ 68$ million, with over 1,500 state and local law enforcement officers trained and granted authorization to enforce federal immigration laws (Nguyen \& Gill, 2015).

In 2008, Secure Communities was introduced. The Secure Communities program (2008-2014) was designed to replace the $287(\mathrm{~g})$ agreements, prioritizing immigration enforcement among non-citizens who had committed serious crimes. The fingerprints of detainees were checked against the databases from the Federal Bureau of Investigation (FBI) and from the Department of Homeland Security (DHS) in order to get information on past criminal arrests, convictions, and immigration history. By the end of 2013, all the nation's 3,181 jurisdictions were participating in Secure Communities (U.S. Immigration and Customs Enforcement (ICE), 2013). The Secure Communities program was replaced by the Priority Enforcement Program (PEP) in 2015, which continued to rely on fingerprint-based biometric data submitted by state and local law enforcement agencies to target unauthorized

\footnotetext{
${ }^{10}$ Key traits of each measure are listed in Appendix B1. All appendices are available at the end of this article as it appears in JPAM online. Go to the publisher's website and use the search engine to locate the article at http://onlinelibrary.wiley.com.
} 
immigrants convicted of specific crimes. ${ }^{11}$ However, the current Administration re-activated the Secure Communities Program in February 2017.

In contrast to most 287(g) agreements and Secure Communities -both of them locallevel police-based initiatives, omnibus immigration laws (2010 to present) are state-wide police-based enforcement measures. Arizona was the first state to sign an omnibus immigration law in 2010. While the content of each omnibus immigration law differs, they often include a "show me your papers' clause", which enables the police to request proper identification documentation during a lawful stop. Nonetheless, in some instances, omnibus immigration laws have gone as far as to require that schools verify students' legal status. ${ }^{12}$

Finally, we also account for the role played on household composition by employment-based immigration enforcement -namely, employment verification mandates (E-Verify). E-Verify can lower household income and, in turn, prove destabilizing for many households, affecting their composition and structure (Bohn, Lofstrom, \& Steven, 2014). Everify is an electronic program that allows employers to screen newly hired workers for work eligibility. The program is administered by the U.S. Department of Homeland Security in partnership with the Social Security Administration. While the use of E-Verify is obligatory in the hiring of federal employees, it has been optional at other levels. Some states have mandated its use, either by public agencies and contractors working for public agencies or, in more extreme cases, by all employers in the state. The first E-Verify mandate was implemented in 2006 in the state of Colorado. With E-Verify, the employer introduces the biographic information (name, social security number, date of birth, citizenship and alien registration number) of the prospective employee into an online program. The software program then cross-checks the prospective employee's records between those in the Social

\footnotetext{
11 See: http://www.dhs.gov/sites/default/files/publications/14_1120_memo_secure_communities.pdf

12 See Alabama's HB56, National Conference of State Legislatures 2012, at: http://www.ncsl.org/research/immigration/omnibus-immigration-legislation.aspx\#Fifty-Three_Omnibus_Bills
} 
Security Administration (SSA) database and the records from the Department of Homeland Security (DHS) to determine whether the worker is authorized to work in United States. If work eligibility cannot be confirmed, the employer receives a "tentative no confirmation" that the worker has to resolve within eight business days. E-Verify has grown rapidly since it was first adopted. The number of participating employers in E-Verify increased by more 400 percent from 1,064 in 2001 to 602,621 by $2015 .^{13}$

\subsection{Children's Living Arrangement and Interior Immigration Enforcement}

A common thread of all the aforementioned interior immigration enforcement initiatives is their intent to curb the number of undocumented immigrants by discouraging their entry and, more importantly, facilitating their apprehension and deportation. Between 2003 and 2011, interior removals increased by roughly 520 percent as the prior interior immigration enforcement initiates were rolling out -in contrast, border removals rose by 76 percent over the same time span (see Figure A3). Altogether, the various programs have been responsible for approximately 1.8 million deportations between 2009 and 2013 alone (Vaughan, 2013).

The intensification of interior immigration enforcement might have affected the living arrangements of U.S. born Hispanic children through a couple of channels. First, through the apprehension and deportation of household heads -many of whom were fathers and main household breadwinners (Capps et al., 2016) (B. R. Capps et al., 2016), interior immigration enforcement might have separated families, increased the number of mothers struggling to make ends meet or the number of relinquished children (Dreby, 2012). In addition, the employment restrictions enforced by E-Verify mandates may have contributed to these patterns by financially restraining families, lowering household income and negatively

\footnotetext{
13 See: http://www.uscis.gov/e-verify/about-program/history-and-milestones
} 
affected the children's living arrangements, even in the absence of apprehensions or deportations of family members.

In this regard, prior reports discuss how children are often left back in the United States in the company of their moms with absent spouses, or in households not at risk of deportation when both parents leave the country (Capps et al., 2007)(R. Capps et al., 2007) . Not surprisingly, the children belonging to such households often find themselves overburdened with adult responsibilities that interfere with their schooling progression (Menjivar, 2006) and adversely impact their health and future employment outcomes (Brabeck \& Qingwen Xu, 2010; Brooks-Gunn, Duncan, \& Maritato, 1997; Delva et al., 2013; Hagan, Castro, \& Rodriguez, 2010). Given the emotional, cognitive and long-run socioeconomic costs of being raised in a single-headed household (Amato, 2005; Chaudry et al., 2010), gaining a better understanding of the collateral damage of heightened enforcement on the families to which these children belong is warranted.

Therefore, in what follows, we explore the impact the intensification of immigration enforcement might have played on the structure of families to which many of the deported fathers of U.S. born children belonged. In particular, we focus on testing two main hypotheses. First, we hypothesize that immigration enforcement has raised: (1) the likelihood that Hispanic, U.S. born children live without their parents in households headed by naturalized relatives or friends unthreatened by deportation, and/or (2) these children's propensity to live with likely undocumented mothers with absent spouses. Second, we hypothesize that such impacts are likely to emanate from police-based immigration enforcement policies directly associated to apprehensions and deportations of undocumented migrants, as opposed to employment verification mandates that also have the potential to affect household structure through financial constraints. 


\section{Data Sources and Samples}

We use various sources of data in our analysis: (1) the American Community Survey (ACS) provided by the Integrated Public Use Microdata Series (Ruggles, et al. 2017), and (2) local and state-level data on the enactment and implementation dates of a number of interior immigration enforcement initiatives, including: 287(g) agreements, Secure Communities, employment verification mandates and omnibus immigration laws.

\subsection{The American Community Survey}

The American Community Survey (ACS) for the 2005 through 2015 period is the main source of data in our analysis. The ACS has many advantages. First, it provides rich demographic, social, economic and housing information of a sufficiently large and representative sample of individuals and the households to which they belong. Approximately 3.5 million randomly sampled households are interviewed on a yearly basis. Secondly, over the 2005 through 2015 period, the ACS allows us to exploit the temporal and geographic variation of immigration policies by consistently identifying the metropolitan area (MSA) where families live. ${ }^{14}$ Third, the 2005 ACS sample is the first yearly sample with a full one-percent sample of the United States. Fourth, the ACS gathers information about ethnicity and citizenship status - key traits, along with educational attainment and length of stay in the United States, when trying to proxy for the likely undocumented immigration status of respondents. Finally, because of its sampling and interview process, the ACS is particularly appropriate to study this population. It conducts interviews without regard to legal status, using the near universe of U.S. addresses to derive its interview sample. ${ }^{15}$

\footnotetext{
14 An alternative geographic identifier in the ACS is the CONSPUMA, but the latter is only available for the years 2005 through 2011. MSAs are integrated by a large urban core and surrounding communities that have a high degree of economic and social integration with the urban core.

${ }^{15}$ As pointed out by Pope (2016), undocumented individuals should not be more or less likely to be interviewed by the ACS based on its sample design. After all, the ACS relies on the Census Bureau's official inventory of known housing units in the United States to generate its sample frame. A subsample of addresses is drawn from the sample frame; therefore, respondents have the same probability of being selected regardless of their
} 
One limitation of representative datasets, such as the ACS, is the lack of information about the legal status of migrants and the representativeness of the potentially undocumented population being surveyed. With regards to the former, the Census Bureau and the Department of Homeland Security estimate that nearly 40 percent of non-citizens are authorized immigrants (Acosta, Larse, \& Grieco, 2014; Baker \& Rytin, 2013). In addition, more than two thirds of unauthorized immigrants in the United States are from Mexico and Central America, with most unauthorized immigrants having low educational attainment (see for example, Bohn \& Lofstrom, 2013; Orrenius \& Zavodny, 2016; Passel \& Cohn, 2009). Hence, following the prior literature (Passel and Cohn 2009, Bohn and Pugatch 2013, Pope 2016, Orrenius and Zavodny 2016), we first use information on the household head's citizenship status, Hispanic ethnicity and low educational attainment (having less than a high school diploma) to proxy for her/his likely undocumented status. Additionally, to address any concerns regarding the possibility that this proxy of likely unauthorized household heads might include college students with non-immigrant visas (i.e. F1 or J1) or low-skilled immigrants with relatively short-lived visas (i.e. H-2A or H-2B), we further restrict our proxy to Hispanic non-citizens without a high school diploma and with more than 5 years of residency in the country. At any rate, as a robustness check, we also experiment with a residual approach initially proposed by (Passel, Lopez, Cohn, \& Rohal, 2014) and subsequently applied by others (e.g. Borjas 2017), to proxy for the likely unauthorized status of the parents. ${ }^{16}$ As we discuss in the robustness checks, results prove robust to the use of this alternative measure. ${ }^{17}$

citizenship status. Furthermore, survey non-response rates are rather low. This is because the data is gathered in various ways -via internet, mail, telephone, and personal visit. First, the household receives a mailed request to respond via internet, with an option to complete a paper questionnaire and return by mail. If there is no response after one month, the Census Bureau follows up with computer-assisted telephone interviews. If there is still no response, the address is selected for computer-assisted personal interviewing. As a result, the Census Bureau reports response rates above 95 percent.

16 According to this approach, a person is deemed to be legally in the United States if s/he satisfy any of the following criteria: arrived before 1980, has U.S. citizenship, receives public benefits, works in the government 
Our interest is in examining how the adoption of tougher immigration enforcement at the local and state levels has influenced the structure of families to which many of the deported fathers of U.S. born children belonged. To that end, we look at the prevalence of two living arrangements among Hispanic U.S. born children: (1) their propensity to reside without their parents in a household headed by relatives or friends, and (2) their likelihood of residing with mothers reporting having their spouse absent.

As noted in the Introduction, we focus on Hispanic U.S. born children, not only because they account for the largest group of children with undocumented parents but, also, because they are the most likely to remain in the United States. ${ }^{18}$ To avoid including potential teen parents as children, we restrict our attention to children 0-15 years old. As a result, the sample used to examine the first outcome is composed of Hispanic, U.S. born children ages 0-15 in households headed by a low-skill (with less than a high school diploma) and long-term Hispanic resident (with 5 or more years of residency in the United States if foreign-born). To examine our second outcome, we focus on Hispanic, U.S. born children ages 0-15 who reside with their married, Hispanic, low-skill and long-term resident moms since information on absent spouses is only available for married individuals.

Table 1 shows some key summary statistics for our two samples of children. Most notably, looking at our outcomes in Panel A, we find that approximately 7.6 percent of U.S. born Hispanic children ages 0-15 live without their parents in households headed by a likely

sector, was born in Cuba, has an occupation that requires licensing, or has a spouse who is a legal immigrant or U.S. citizen. Everyone else is likely undocumented.

17 Other methods to proxy for the likely undocumented status of immigrants used in the literature include the use of out-of-sample predictions using a dataset containing information on the legal status of immigrants (i.e. a donor dataset). Unfortunately, the representativeness of the immigrant population in such data sets is often questionable. An exception appears to be the Survey of Income and Program Participation (SIPP). However, its representativeness of the undocumented immigrant population, as well as its adequacy to predict immigrants' undocumented status in later years is debatable given that the last module containing information on immigrants' legal status is from 2008 -prior to the drastic increase in migrant deportations. Furthermore, as noted in (Van Hook, et al., 2015), the SIPP is not valid for doing inferences of policy impacts at the state level. Hence, its validity for doing inference at the MSA level is doubtful.

18 At any rate, in our robustness checks, we experiment with expanding the sample to include non-citizen children. As we discuss therein, our results prove robust to the inclusion of this much smaller and heterogeneous sample. 
undocumented individual. An additional 9.5 percent resides without their parents in households headed by naturalized immigrants, and 18 percent reside without their parents in a household headed by natives. In turn, Panel B reveals that roughly 3.3 percent of Hispanic, U.S. born children ages 0-15 reside with a likely undocumented mom whose spouse is absent. The share living with a naturalized mom whose spouse is absent is 5.2 percent, and the share living with a native mom with an absentee spouse is 10.5 percent.

\subsection{Enforcement Data}

In order to exploit the geographic and temporal variation in the adoption of various immigration enforcement initiatives described in Section 2 and Table B1 in the Appendix ${ }^{19}$, we gather historical and current data. Specifically, data on the implementation of $287(\mathrm{~g})$ agreements at the state level is gathered for the 2005 through 2015 period from the ICEs 287(g) Fact Sheet website, (Amuedo-Dorantes \& Bansak, 2014; Kostandini, Mykerezi, \& Escalante, 2013). Since the ICE website contains only a list of the current active agreements, we review old websites and prior research using these agreements to assemble a complete dataset spanning from 2005 to 2015. Once we have the start date of each 287(g) agreement, we calculate the period of time during which these agreements have been in place.

Data on the rolling of the Secure Communities (SC) program is available at the county level since 2008 using ICE's Activated Jurisdictions document (U.S. Immigration and Customs Enforcement (ICE), 2017b). Data on state level initiatives, such as omnibus immigration laws (OILs) and employment verification (E-Verify) mandates, is gathered from the National Conference of State Legislature's website (Legislatures, 2017). These sources allow us identify the date, state and type of OILs or E-verify mandates signed.

\footnotetext{
${ }^{19}$ All appendices are available at the end of this article as it appears in JPAM online. Go to the publisher's website and use the search engine to locate the article at http://onlinelibrary.wiley.com.
} 
Since these immigration policies have been enacted at different geographic levels and points in time, we construct an index that serves as a proxy for the intensification of immigration enforcement and provides several advantages over inclusion of multiple policy indicators. ${ }^{20}$ First, as we shall describe in what follows, the index not only addresses the distinct geographic coverage of various measures (some at the county level, others at the state level) through the construction of a population weighted measure of immigration enforcement but, in addition, it accounts for the number of months each measure was in place in that particular year. In that manner, it allows us to capture the depth and intensity of immigration enforcement in a given MSA, as opposed to just whether enforcement existed or not.

Second, immigration enforcement is an interconnected system administered by various federal, state, and local authorities and agencies with similar missions and, some measures, such as Secure Communities, were enacted as a continuum of prior existing measures, like the $287(\mathrm{~g})$ program. Not only are the various immigration enforcement initiatives correlated but, in addition, the effectiveness of any given measure is often linked to its combination with other initiatives. The index allows us to better address this interconnectedness by combining the various policies into an index.

Third, the index provides a more manageable and comprehensive way of measuring and assessing the overall impact of intensified interior immigration. ${ }^{21}$ At any rate, in heterogeneity analyses, we distinguish between police-based and employer-based enforcement measures given the distinct resources they rely upon (police vs. employers), as well as their distinctive consequences. As noted earlier, the former are responsible for the

\footnotetext{
${ }^{20}$ It is worth noting that the index is a proxy of the intensity of immigration enforcement to which respondents in a particular MSA might be exposed to. At the end of the day, the true intensity of any enforcement measure will inevitably vary across jurisdictions as each one is different and might implement similar measures more or less strictly depending on who is in charge of its implementation or other unobserved local traits.

${ }^{21}$ Otherwise, the analysis quickly becomes intractable as one assesses parallel pre-trends or instruments for five different overlapping polices.
} 
growing number of apprehensions and deportations, which can directly alter the household structure, whereas the latter can alter household composition via its negative impact on income, which can be a destabilizing factor for many families. ${ }^{22}$

Hence, we first compute the following indexes for each policy measure, $k$, and for every year, $t$, in our sample:

$$
E I^{k}{ }_{m t}=\frac{1}{N_{2000}} \sum_{\boldsymbol{a} \in \boldsymbol{m}} \frac{1}{12} \sum_{\boldsymbol{c}=\mathbf{1}}^{\mathbf{1 2}} \mathbf{1}\left(E_{c, a}\right) P_{a, 2000}
$$

where $k$ refers to each of the enforcement initiatives being examined, i.e.: $287(\mathrm{~g})$ local, 287(g) state, Secure Communities, omnibus immigration laws and E-verify, and $t=2005 \ldots 2015$. The indicator function: $\mathbf{1}\left(E_{c, a}\right)$ informs about the implementation of a particular policy or measure in local area $a$ at time (month) $c$. As noted earlier, the above index takes into account: (1) the number of months during which the policy has been in place in any given year, as well as (2) the population of each local area in question prior to the rollout of the various immigration enforcement initiatives - that is, in the year 2000. As such, the summation over the 12 months in the year captures the share of months during which the measure in question was in place in any given year. To weigh it population-wise, we use the term: $P_{a, 2000}$-namely, the population of local area $a$ according to the 2000 Census, as well as $N$-the total population in MSA $m .^{23}$

To derive a comprehensive measure of the immigration enforcement to which children living in MSA $m$ in year $t$ are exposed to, we sum the indices for each enforcement initiative $k$ at the (MSA $m$, year $t$ ) level as follows:

\footnotetext{
22 Despite the correlation among the various types of measures, we also display the results when we distinguish among the five different initiatives.

${ }^{23}$ For example, if an MSA is comprised of two local areas, the Enforcement Index for a given immigration enforcement measure, such as Secure Communities (SC), in MSA $m$ and year $t$ would be given by:

$E I_{m, t}^{S C}=\frac{\text { Months_coverage }}{12} * \frac{\text { Area } 1_{\text {Pop }}}{M S A_{-} P o p}+\frac{\text { Months_coverage }}{12} * \frac{\text { Area } 2_{-} P o p}{M S A_{-} P o p}$
} 
Total Enforcement ${ }_{m, t}=\sum_{k \in K}^{K} E I_{m, t}^{k}$ for every MSA $m$ and $t=2005 \ldots 2015 .{ }^{24}$

As shown in Table 1, the immigration enforcement index, which varies between 0 and 5, averaged between 0.94 and 1 for the samples and time period under consideration. Figure A4 illustrates the growing funding of Immigration Customs Enforcement (ICE) -typically in charge of interior immigration enforcement. The temporal variation in interior immigration enforcement is also evident from the trends in the various immigration enforcement indexes we work with -all plotted in Figure A5. The intensification of immigration enforcement parallels the drastic increase in removals from the interior of the United States displayed earlier on in Figure A3. In addition, Figure A6 shows the geographic variation in immigration enforcement, by displaying the progressive rollout of tougher immigration enforcement across MSAs in the country between 2005 and 2015. Together, all three graphs (A4, A5 and A6) underscore the ample temporal and geographic variation crucial in identifying its impact on our outcomes of interest.

\section{Empirical Strategy}

To gauge the effect of intensified immigration enforcement on the structure of families to which many of the deported fathers of U.S. born children belonged, we start by estimating the following benchmark model specification, which exploits the temporal and geographic variation in the enforcement index as follows:

$$
\text { (3) } y_{i, m, t}=\alpha+\beta_{1} \text { Total Enforcement }{ }_{m, t}+X^{\prime}{ }_{i, m, t} \beta_{2}+Z^{\prime}{ }_{s, t} \beta_{3}+\gamma_{m}+\theta_{t}+\gamma_{m} t+\varepsilon_{i, m, t}
$$

where $y_{i, m, t}$ is our outcome variable -namely: the $i$ th child's living arrangement in MSA $m$ and year $t$. As noted earlier, we specifically look at the prevalence of two living arrangements among Hispanic U.S. born children: (1) their propensity to reside without their

\footnotetext{
${ }^{24}$ In posterior heterogeneity analyses, the five individual indices described by equation (1) are grouped into police-based and employment-based measures. The police_based enforcement $t_{m, t}=\sum_{k=1}^{4} E I_{m, t}^{k} \quad$ or $k=\mathrm{SC}$, MSA- $287 \mathrm{~g}$, State- $287 \mathrm{~g}$, and OIL, whereas as employment_based enforcement ${ }_{m t}=E_{-}$verif $_{m t}$. We also experiment with performing the analysis using the five separate indices for each immigration enforcement measure.
} 
parents in a household headed by relatives or friends, and (2) their likelihood of residing with mothers reporting having absent spouses.

Total Enforcement f $_{m, t}$ is the immigration enforcement index described in the prior section, which helps encompass the multiplicity of enforcement measures implemented over the time period under consideration, providing us with a useful proxy for the intensity of enforcement to which the child is exposed to. $X^{\prime}$ is a vector of demographic characteristics likely correlated with the child's living arrangement, as is the case with the child's age and its squared term, as well as the household head's years of education and length of U.S. residency, if foreign-born. ${ }^{25}$ The vector $Z$ contains information on the welfare generosity at the state level, ${ }^{26}$ which has been shown to affect child living arrangements(Bitler et al., 2006) $)^{27}$ and whether the state has enacted a Trust Act. Trust Acts are adopted with the purpose of increasing trust and community cooperation with the police following the prior implementation of programs, such as $287(\mathrm{~g})$ agreements, increasing information sharing between local, state, and federal government agencies (Fagan \& Meares, 2008; Fagan \& Tyler, 2008; Skogan \& Frydl, 2004; Tyler, 2010). Accounting for them allows us to more accurately capture the impact of intensified immigration enforcement, which should be lax or close to null in those areas. Table B2 in the Appendix provides a detailed description of each variable. ${ }^{28}$

\footnotetext{
${ }^{25}$ In the case of natives, this term equals their age.

${ }^{26}$ A dummy variable that equals 1 if the state allowed previously eligible immigrants to continue to receive benefits similar to those before the 1996 welfare reform, which imposed strict restrictions on eligibility for noncitizens. The dummy equals 0 , otherwise.

${ }^{27}$ In an intermediate model specification (shown as specification no. 3 in Tables 2-3), we experiment with controlling for a number of potentially endogenous MSA traits. To address that limitation, we measure the MSA characteristics in the year 2000 -that is, prior to the implementation of any of the immigration enforcement measures considered herein. These traits include the unemployment rate and the share of Hispanics in the MSA, as well as the share of people voting republican in the state. To address their overtime variation, these traits are interacted with a time trend.

${ }^{28}$ All appendices are available at the end of this article as it appears in JPAM online. Go to the publisher's website and use the search engine to locate the article at http://onlinelibrary.wiley.com.
} 
Finally, equation (3) includes temporal and geographic fixed-effects (i.e. dummies for each year and MSA), as well as MSA-specific time trends to capture other unobserved fixed and time-varying traits potentially affecting our outcomes that we might fail to account for. Standard errors are clustered at the MSA level. ${ }^{29}$

The coefficient of interest is $\beta_{1}$, which captures the relationship between the intensity of local and state-level immigration enforcement and our outcome variables. A positive coefficient would be consistent with our prediction that tougher enforcement increases the incidence of: (1) children living without parents, and (2) children living with mothers who report having an absentee spouse following the separation of the family unit through parental deportations.

\section{Intensified Immigration Enforcement and Children's Living Arrangements}

\subsection{Main Findings}

As noted earlier, our main aim is to assess how the adoption of tougher immigration enforcement at the local and state levels has influenced the structure of families to which many of the 4.5 million of U.S. born children with an undocumented parent belong. To that end, Table 2 reports on our main outcome of interest -namely, the impact that intensified immigration enforcement is having on the children's likelihood of living without their parents in households headed by relatives or friends. We distinguish according to whether the household head is a likely undocumented immigrant, a naturalized immigrant or a U.S. native since parents might prefer leaving their children in a household unthreatened by deportations (Capps et al., 2007)(R. Capps et al., 2007) . As noted earlier, equation (3) is estimated on a sample of U.S. born Hispanic children in households headed by low-skill and long-term

\footnotetext{
29 Because some of the children might reside in the same household, we also experiment with running the analysis at the household level -that is, looking at the likelihood that one of the households included in our sample is host to one of the living arrangements being examined. As we explain in our robustness checks, the results from such an exercise corroborate our findings using child level data.
} 
Hispanic residents using Ordinary Least Squares (OLS). We estimate a number of specifications that progressively add controls to assess the robustness of our findings to the estimation of more saturated models.

Focusing on the most complete model specification, we find that a one standard deviation increase in the enforcement index (equal to the average level of immigration enforcement for the period under consideration) raises the children's propensity to live without their parents in a household headed by naturalized relatives or friends by 18.8 percent. $^{30}$ However, immigration enforcement does not appear to raise these children's propensity to reside without their parents in a household headed by a likely undocumented or native relative/friend. Overall, the results suggest that, perhaps, when deported, parents leave their offspring in households headed by other immigrants who are, nonetheless, naturalized.

Since most deportees are men, many of them fathers, Table 3 further looks at the impact of intensified immigration enforcement on the children's propensity to reside with mothers whose spouses are absent. Because the ACS only gathers information on the absentee status of spouses, the sample used to learn about this outcome is somewhat smaller. As in Table 2, we continue to estimate the model separately for children whose mothers are likely undocumented, naturalized or U.S. natives. As shown in Table $\mathrm{C}$ in the appendix ${ }^{31}$, the majority of children with a likely undocumented parent have parents who are both likely undocumented. Hence, immigration enforcement should particularly raise the likelihood that children with a likely undocumented parent might reside with likely undocumented mothers who report having an absent spouse.

\footnotetext{
30 The standard deviation of the enforcement index is 0.94 and, on average, 9.5 percent of the children in our sample live without their parents in a household headed by a naturalized and low-skilled Hispanic resident. Therefore: $\{[(0.019) * 0.94] / 0.095\}=0.188$ or 18.8 percent.

31 All appendices are available at the end of this article as it appears in JPAM online. Go to the publisher's website and use the search engine to locate the article at http://onlinelibrary.wiley.com.
} 
As in Table 2, we estimate a number of specifications that progressively add controls to assess the robustness of our findings. Focusing, once more, on the most complete model specification, we find that a one standard deviation increase in the enforcement index raises the children's likelihood of living with likely undocumented mothers with absent spouses by 20 percent. ${ }^{32}$ However, it does not appear to raise their propensity to reside with naturalized or U.S. born mothers with absent spouses -a smaller share of whom are likely married to unauthorized men. These results are easily understood in light of the fact that most undocumented fathers are married to likely undocumented women. Through the deportation of fathers, intensified immigration enforcement ends up primarily splitting households where both parents are likely undocumented, leaving the mother alone to take care of their U.S. born offspring.

\subsection{Robustness Checks}

Much of the intensification of immigration enforcement coincided with the onset of the Great Recession. As such, one might be concerned that the estimated impact of intensified immigration enforcement is capturing the effects of the recession despite the inclusion of year fixed-effects addressing macroeconomic fluctuations (e.g. economic downturns) and MSA-specific time trends. To address that concern, we re-estimate equation (3) using another sample of children who, despite being similar in terms of residing in households headed by low-skill and long-term U.S. residents/natives, should have been less likely to be negatively impacted by intensified immigration enforcement, as would be the case with white non-Hispanic children. To the extent that they are not Hispanic, they are less likely to have Hispanic parents - one of the various identifying traits of likely undocumented immigrants.

\footnotetext{
32 The standard deviation of the enforcement index is 0.94 and, on average, 3.3 percent of Hispanic children live with likely undocumented moms whose spouses are absent. Therefore: $\{[(0.007) * 0.94] / 0.033\}=0.20$ or 20 percent.
} 
Table 4 displays the results from estimating these children's propensity to reside without any of the parents in a household headed by a relative or friend, as well as their likelihood to live with mothers with an absentee spouse. As we would expect from this falsification test, there is no statistically significant evidence of immigration enforcement having an impact on any of the aforementioned events, despite the fact that white nonHispanic children residing in household with low-skilled heads were severely hit by the economic downturn (Hoynes \& Schanzenbach, 2012)(Hoynes, Miller, \& Schaller, 2012).

Subsequently, we assess the robustness of our findings to the use of an alternative proxy of the likely undocumented status of the household head or mother, as well as to the exclusion of potential outliers from our sample. Specifically, in Panel A of Table 5, we display our main results using, instead, a proxy for the likely undocumented status of household heads or mothers constructed following the residual method initially proposed by Passel et al., (2014) and subsequently applied by others (e.g. Borjas 2017). According to this method, a person is deemed to be legally in the United States in s/he satisfy any of the following criteria: arrived before 1980, has U.S. citizenship, receives public benefits, works in the government sector, was born in Cuba, has an occupation that requires licensing, or has a spouse who is a legal immigrant or U.S. citizen. Everyone else is likely undocumented. Using this alternative definition, we continue to find evidence of tougher immigration enforcement being associated to a higher likelihood of residing without parents or with mothers whose spouses are absent. In particular, the same one standard deviation increase in immigration enforcement from earlier would raise the children's propensity to live without their parents by 28 percent, and their probability of residing with moms with absent spouses by 14 percent. $^{33}$ These impacts are in line with those found in Tables 2 and 3, respectively.

\footnotetext{
33 The standard deviation of the enforcement index is 0.94 and, on average, 8 percent of the children in our sample live without their parents in a household headed by a naturalized and low-skilled Hispanic resident. Therefore: $\{[(0.024) * 0.94] / 0.08\}=0.28$ or 28 percent. Similarly, an average of 2.7 percent of Hispanic children
} 
Additionally, we explore the possibility that our findings might be driven by the harsher implementation of immigration enforcement in some counties. Of particular note in the literature is the case of Maricopa County in Arizona. Sheriff Joe Arpaio has been an extreme advocate of tough immigration enforcement, labelling himself as "America's Toughest Sheriff". ${ }^{34}$ Hence, in Panel B of Table 5, we re-estimate our models excluding Maricopa County. As can be seen from our estimates in that table, our findings prove robust to the exclusion of that outlier. ${ }^{35}$

To conclude, we also experiment with expanding our sample of children to include their similar non-citizen counterparts. As noted in the Introduction, including non-citizen children does not increase our selected sample by much. The estimates, shown in Panel C of Table 5, continue to support our prior findings. Specifically, the same one standard deviation increase in immigration enforcement would raise the children's propensity of living without their parents in households headed by a naturalized migrant by 16 percent, and their likelihood of living with likely undocumented mothers with absentee spouses by 36 percent..$^{36,37}$

live with likely undocumented moms whose spouses are absent. Therefore: $\{[(0.004) * 0.94] / 0.027\}=0.14$ or 14 percent.

34 "Another Plot against Tough Sheriff, With a Twist" By Michael Janofsky, The New York Times, May 16, 2002. Available at: http://www.nytimes.com/2002/05/16/us/another-plot-against-tough-sheriff-with-a-twist.html 35 Our findings prove robust to the exclusion of other counties that have been known to be tough on immigration enforcement, such as Cameron County in Texas. These results are available from the authors.

${ }^{36}$ The standard deviation of the enforcement index is 0.94 and, on average, 6 percent of the children in our sample live without their parents in a household headed by a naturalized and low-skilled Hispanic resident. Therefore: $\{[(0.013) * 0.94] / 0.06\}=0.16$ or 16 percent. Likewise, an average of 4 percent of Hispanic children live with likely undocumented moms whose spouses are absent. Therefore: $\{[(0.008) * 0.94] / 0.04\}=0.36$ or 36 percent.

37 Finally, we also experiment with performing the analysis at the household level to address the fact that some households might accommodate more than one child. The results, available from the authors, provide support for our findings using individual child level data. The same increase in immigration enforcement raises the propensity that households in our sample might accommodate children who do not reside with their parents, or children who reside with likely undocumented mothers with absentee spouses, by 24 percent and 30 percent, respectively. 


\section{Identification}

Thus far, we have shown how the intensification of immigration enforcement can raise the propensity of Hispanic U.S. born children to reside: (1) without their parents in a household headed by naturalized relatives or friends, or (2) with likely undocumented mothers with absent spouses. We have also shown how these findings are unique to Hispanic, U.S. born children, as opposed to non-Hispanic white children, and how they are not driven by the recession, the particularly tough position on immigration enforcement adopted by Maricopa County in Arizona, the focus on U.S. born children, or by having more than one child residing in the same household. Yet, the validity of our identification approach and findings relies on a number of assumptions we address in what follows.

\subsection{Anticipated or Pre-Existing Impacts}

A first assumption for the validity of our estimates is that the impact of intensified enforcement did not pre-date the implementation of tougher enforcement itself. To assess whether that was the case, we re-estimate equation (3), this time adding a full set of dummies spanning from six years prior to the adoption of any initiative in the MSA in question. In that manner, we are able to gauge if changes in the likelihood of having one of the two living arrangements considered herein preceded the adoption of tougher enforcement measures in each MSA as follows:

(4) $y_{i, m, t}=\alpha+\sum_{b=-6}^{-1} \delta_{b} D_{m, b}+\beta_{1}$ Total Enforcement ${ }_{m, t}+X_{i, m, t}^{\prime} \beta_{2}+Z_{m, t}^{\prime} \beta_{3}+$

$$
+\gamma_{m}+\theta_{t}+\gamma_{m} t+\varepsilon_{i, m, t}
$$

where $D_{m, b}$ is a dummy for $b$ years prior to the enforcement index turning positive in a particular MSA. Note that, because the adoption of these initiatives occurred at different points in time across MSAs, $D_{1}$ might be equal to 2006 for some MSAs, 2007 for others, and so on. 
Table 6 shows the results from estimating equation (4) via OLS. It is evident that the higher likelihood of living without either parent in a household headed by naturalized relatives or friends did not precede the implementation of tougher immigration enforcement, as none of the coefficients for the preceding years are statistically different from zero. Likewise, the estimates in Panel B of Table 6 confirm that the increased likelihood of living with a likely undocumented mom whose spouse is absent did not pre-date the adoption of tougher immigration enforcement measures at the MSA level. Furthermore, the point estimates on our key regressors continue to be statistically different from zero and of similar magnitude to the ones in Table 2, Panel B, and Table 3, Panel A.

\subsection{The Endogenous Adoption of Immigration Enforcement}

A second concern in any policy assessment refers to the potential endogeneity of the policy itself. While understandably not random, the adoption of tougher immigration enforcement needs to be exogenous to our outcome of interest -the children's living arrangements. One way to assess if that is a reasonable assumption is to examine if the adoption timing at each MSA is correlated to the incidence of the children's living arrangements prior to the adoption of any enforcement. To that end, we aggregate the data at the MSA level and estimate the following regression:

$$
\text { EI Year }{ }_{m}=\alpha+X_{m}^{0} \beta+Z_{m}^{0} \mu+\gamma_{s}+\varepsilon_{m}
$$

where EI Year ${ }_{m}$ is the year in which MSA $m$ enacted its first enforcement measure. The vector $\mathrm{X}_{m}^{0}$ represents either: (1) the share of children living without their parents in a household headed by a naturalized relative or friend, or (2) the share of children residing with likely undocumented mothers whose spouses are reported absent, in MSA $m$ prior to the adoption of any enforcement. The next vector, $Z_{m}^{0}$, contains the following MSA level characteristics: the average unemployment rate, the share of Hispanics in the MSA, the share of people voting the republican party and the share of children receiving TANF -all measured 
prior to the adoption of any of the enforcement measures. ${ }^{38}$ Equation (5) can be estimated using data from the beginning of our sample period, i.e. from $2005,{ }^{39}$ including state fixed effects $\left(\gamma_{s}\right)$, and clustering standard errors at the state level.

Alternatively, one can estimate an equation similar to equation (5) where, instead of predicting the timing of the adoption of tougher immigration enforcement itself, we predict the initial level of immigration enforcement at the MSA. That is:

$$
E I_{m}=\alpha+X_{m}^{0} \beta+Z_{m}^{0} \mu+\gamma_{s}+\varepsilon_{m}
$$

where $E I_{m}$ stands for the value of the immigration enforcement in MSA $m$ when tougher enforcement was first implemented. In both instances, when $\beta=0$, children's living arrangements in the MSA did not help predict the enactment date or initial level of interior immigration enforcement in the MSA.

The results from both of these exercises are displayed in Table 7. Regardless of the outcome in question, we find that none of the incidence rates of the two children's living arrangements in the MSA prior to the adoption of stricter enforcement measures seems to have played a significant role in the adoption timing or in the initial level of immigration enforcement at the MSA. As such, while not random, the timing of adoption of tougher immigration enforcement or the initial level of immigration enforcement do not appear to be explained by changes in the outcomes of interest to us in this study.

\subsection{The Non-random Location of Immigrants}

A last challenge when assessing the impacts of any policy on immigrant families is the non-random residential location of immigrants themselves. This is particularly true when examining the living arrangements of children with likely undocumented parents. After all,

\footnotetext{
38 As explained in footnote no. 26, the vector $Z$ included welfare benefits, as well as these traits. They enter in specification no. 3 in Tables 2 and 3 interacted with a time trend. Nevertheless, they drop of the most complete model specification (specification no. 4) once MSA specific time trends are added.

${ }^{39}$ We exclude from this analysis MSAs in the state of Florida, which were the only ones that had already implemented tougher immigration enforcement measures (the state level 287(g) signed by Florida in 2002). Results do not significantly differ, however, when Florida is included.
} 
unauthorized migrants might respond to intensified enforcement by moving to safer areas with less enforcement. In that case, we might not find a significant impact of tougher enforcement on the living arrangements of children in our sample. Note, as well, that the downward bias described above is likely to have been greater with respect to the likelihood of residing with a likely undocumented mom, since she would be the target of intensified immigration enforcement. This is not the case for children living in households headed by naturalized individuals, unless such households are mixed-status households with other likely undocumented members.

To assess if the aforementioned biases are substantial, we use instrumental variable (IV) methods to instrument for the children's likely exposure to tougher immigration enforcement. Because we have already shown that the adoption of tougher immigration enforcement by the MSA does not appear to have been driven by our outcomes of interest, we construct a shift-share instrument in which the shift is the level of immigration enforcement adopted by each MSA in any given year (the policy itself). The share is the likely location of children in our sample based on information on past residential choices of likely undocumented immigrants from the same countries of origin as their parents or household heads prior to the enactment of the enforcement measures being examined (in the spirit of Bartel 1989; Card 2001; Cortes and Tessada 2011, among many others). Specifically, we use data from the year 2000 ACS to construct a share capturing what the most probable location of undocumented immigrants from the same country of origin as the parents or household heads would have been in each MSA in the absence of interior immigration enforcement: ${ }^{40}$

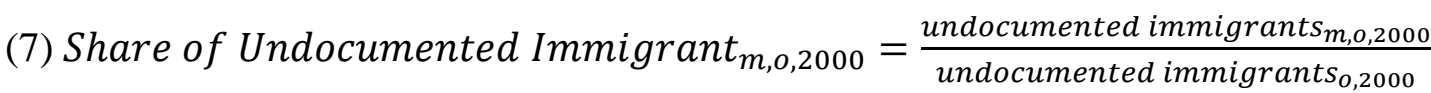

\footnotetext{
${ }^{40}$ We are using the population in 2000 given that we cannot consistently match the MSAs in 1980 or 1990 with those in 2000 onwards.
} 
Subsequently, we interact the share in equation (7) with the shift-namely, the level of immigration enforcement for each MSA in question in any given year. For this instrument to be valid, it needs to be highly correlated to the non-instrumented exposure to tougher immigration enforcement. This might be the case due to the entrenched tendency for immigrants to locate in areas with established networks of their compatriots (Bartel 1989; Card 2001; Cortes and Tessada 2011, among many others).

Table 8 shows the IV estimates for both outcomes. When examining our first outcome, we focus our attention on mixed-status households since they are the ones most likely to have made residential decisions based on intensified immigration enforcement. The sample for the second outcome is the same as in Table 3, Panel A. The lower rows of Table 8 confirm that the IV is a good instrument. Specifically, the F-stats from the first stage regressions are equal to 23.49 and 35.55 , respectively; thus, larger than the recommended size of 10 (Stock \& Yogo, 2005). The estimated coefficients from the first stage regressions are positive and statistically significant, confirming the entrenched tendency for immigrants to locate in areas with established networks of their countrymen. Additionally, the same one standard deviation increase in immigration enforcement (equivalent to 0.94) increases the propensity of living without parents in a household headed by a naturalized relative or friend by 28 percent (as opposed to approximately 19 percent in Table 2, Panel B). ${ }^{41}$ Similarly, tougher immigration enforcement substantially raises the probability of living with a likely undocumented mom who reports having an absent spouse. Specifically, a one standard deviation increase in immigration enforcement raises the likelihood of this living

\footnotetext{
${ }^{41}$ The standard deviation of the enforcement index is 0.94 and, on average, 12 percent of the children in our sample live without their parents in a household headed by a naturalized and low-skilled Hispanic resident. Therefore: $\{[(0.036) * 0.94] / 0.12\}=0.28$ or 28 percent.
} 
arrangement by 51 percent, as opposed to 20 percent in Table $3 .{ }^{42}$ While the IV estimates are, certainly, more imprecisely estimated, they serve to confirm that, if anything, our OLS estimates are probably lower bound estimates of the true impact of intensified enforcement.

\section{Policy Channels}

Thus far, we have documented how the intensification of immigration enforcement appears to raise the propensity of two types of living arrangements among U.S. born Hispanic children with a likely undocumented parent or household head: (1) living without parents in households headed by naturalized relatives or friends, and (2) living with likely undocumented mothers who report their spouses as absent. The rationale behind these findings, which are unique to Hispanic children and survive a number of identification and robustness checks, is that intensified immigration enforcement splits the families of these children via the deportation of family members.

To assess if the observed impacts are likely occurring through the splitting of households that follows the deportation of a parent, we distinguish between two types of measures: (1) employment-based enforcement, and (2) police-based enforcement. The former consist of employment verification mandates checking the work eligibility of immigrants, which could potentially impact children's living arrangements via their impact on the parents' earnings. The latter involve the local and state police and are directly linked to the apprehension and deportation of undocumented immigrants. If the measured impacts of intensified enforcement in Table 2, Panel B, and Table 3, Panel A, were indeed capturing the impact of deportations, we would only expect police-based enforcement -responsible for deportations from the interior, to have a significant impact on the living arrangements of children.

\footnotetext{
42 The standard deviation of the enforcement index is 0.94 and, on average, 3.3 percent of Hispanic children live with likely undocumented moms whose spouses are absent. Therefore: $\{[(0.018) * 0.94] / 0.033\}=0.51$ or 51 percent.
} 
Table 9 displays the estimates from this additional robustness check. Panel A shows that one standard deviation increase in police-based immigration enforcement raises the children's likelihood of residing without their parents in a household headed by a naturalized relative or friend by 19 percent. ${ }^{43}$ Likewise, the same increase in police-based immigration enforcement raises the children's likelihood of residing with likely undocumented mothers with absent spouses by 38 percent. $^{44}$ However, employment-based measures, which could impact family composition by placing severe financial constraints on the household, do not have a statistically significant impact on the children's living arrangements despite having a coefficient that is not statistically different from that of police-based immigration enforcement in size.

Table 10 shows the results from estimating our models when we further split our immigration enforcement index into individual policy indexes. Supporting the results in Table 9, we find that local, police-based immigration enforcement measures appear to drive the found impacts. Specifically, a one standard deviation increase in immigration enforcement through Secure Communities - the one program that had a nationwide reach, raises the children's likelihood of residing without their parents in a household headed by a naturalized relative or friend by 16 percent. ${ }^{45}$ Likewise, a one standard deviation increase in immigration enforcement through $287(\mathrm{~g})$ agreements signed by local law enforcement with ICE -thus, underscoring the community's choice to emphasize immigration enforcementraises the children's likelihood of residing in households singly headed by likely

\footnotetext{
43 The standard deviation of the police based immigration enforcement index is 0.77 and, on average, 9.5 percent of the children in our sample live without their parents in a household headed by a naturalized and lowskilled Hispanic resident. Therefore: $\{[(0.019) * 0.77] / 0.095\}=0.19$ or 19 percent.

44 The standard deviation of the police based immigration enforcement index is 0.79 and, on average, 3.3 percent of Hispanic children live with likely undocumented moms whose spouses are absent. Therefore: $\{[(0.011) * 0.79] / 0.033\}=0.38$ or 38 percent

${ }^{45}$ The standard deviation of the secure communities, displayed in Table D in the Appendix, is 0.47. All appendices are available at the end of this article as it appears in JPAM online. Go to the publisher's website and use the search engine to locate the article at http://onlinelibrary.wiley.com. On average, 9.5 percent of Hispanic children live without parents. Hence, the estimated impact is given by: $[(0.032 * 0.47) / 0.0954]=0.16$ or 16 percent.
} 
undocumented mothers with absent spouses by 17 percent. ${ }^{46}$ Finally, even when these two programs do not display statistically significant coefficients, they have similar estimated impacts, but large standard errors suggesting their impacts are not precisely estimated.

\section{Summary and Conclusions}

Since 9/11, we have witnessed an unprecedented escalation of interior immigration enforcement that led to unparalleled increases in deportation figures -the vast majority of which were men, many of whom were fathers of U.S. born children. In this paper, we gauge the impact that the escalation of immigration enforcement is having on the structure of families to which many of the deported fathers of U.S. born children belonged. We do so by focusing on the role that intensified immigration enforcement has played on the prevalence of two living arrangements among Hispanic U.S. born children in households headed by Hispanic, low skill and long-term residents: (1) residing without their parents, and (2) living with mothers whose spouses are absent.

We find that the toughening of immigration enforcement has raised the exposure of these children to living without their parents in a household headed by a naturalized immigrant, as well as their propensity to live with likely undocumented mothers with absent spouses. The first results points to the possibility that, through the deportation of one or both of the parents, children might be left behind living with relatives or friends who are not at risk of deportation. The second finding further points to the possibility that, through the deportation of fathers, intensified immigration enforcement ends up primarily splitting households where both parents are likely undocumented; leaving the mother alone to take care of their U.S. born offspring. Our findings prove robust to a number of identification and

\footnotetext{
46 The standard deviation of the local 287(g) agreements, also displayed in Table D in the Appendix, is 0.47. All appendices are available at the end of this article as it appears in JPAM online. Go to the publisher's website and use the search engine to locate the article at http://onlinelibrary.wiley.com. On average, 3.3 percent of Hispanic children live in a singly headed household with moms who report their spouses as being absent. Therefore, the estimated impact is given by: $\{[(0.013) * 0.47] / 0.033\}=0.17$ or 14 percent.
} 
robustness checks addressing the many challenges researchers face when working with this population, including its difficult identification and their endogenous sorting across MSAs. Overall, the various checks reveal that the observed impacts originate from immigration enforcement more directly linked to deportations, as is the case with police-based enforcement involving local and state police -specifically, Secure Communities and local 287(g) agreements between the local police and Immigration Customs Enforcement (ICE).

The implications of these findings go beyond informing the immigration policy debate, to also advise policymakers concerned about the design of policies that address children's inequities associated with their parents' immigration statuses. An estimated 7,823 additional children would start living with likely undocumented mothers with absentee spouses if immigration enforcement were to intensify by one standard deviation -an enforcement level approximately equal to its average level over the period under analysis. ${ }^{47}$ Likewise, approximately 9,018 children would start living without their parents in households headed by a naturalized relative or friend. ${ }^{48}$ These impacts are non-negligible in light of the extensively documented consequences of growing up without parents or with only one parent. Children growing up without their biological parents often find themselves at a disadvantage (Case, Lin, \& McLanahan, 2000) and they are more likely to engage in criminal activities (Bezin, Verdier, \& Zenou, 2018). Likewise, researchers have documented the negative consequences of parental deportation in children -consequences that range from an inferior schooling progression (Menjivar, 2006) to worse health and future employment outcomes (Brabeck \& Qingwen Xu, 2010; Brooks-Gunn et al., 1997; Delva et al., 2013; Hagan et al., 2010). Finally, it is well-known that children raised in single-parent household

\footnotetext{
47 In 2005, an estimated 39,112 children in our sample were living with likely undocumented mothers with absentee spouses. Hence, a one standard deviation increase in immigration enforcement would add 7,823 children to that pool (i.e. the estimated 20 percent increase).

48 In 2005, an estimated 56,482 children in our sample were living without their parents in households headed by a naturalized relative or friend. A one standard deviation increase in immigration enforcement would raise the size of that group by 9,018 children (i.e. the estimated 19 percent increase).
} 
are more likely to experience teen-age pregnancies, drop out of school, have worse noncognitive skills and endure more frequent and longer unemployment spells later on in life (see for example Adda et al., 2011; McLanahan, 2004).

Gaining a better understanding of the impacts of intensified immigration enforcement is not only imperative given the consequences for these children, all of them U.S. citizens, but also in light of the executive orders signed by President Trump in 2017 and the overall strengthening of immigration enforcement since February 2017. A recent example has been the adoption of the "zero tolerance" policy in April 2018, which during the two subsequent months split families to criminally prosecute anyone who was caught crossing the U.S. border, including families who were seeking asylum. While parents were transferred to the custody of the U.S. Marshals Service to be prosecuted, detained, imprisoned and, perhaps, deported from the country, their children were taken into government custody and held with little or no contact with their parents -a practice condemned by United Nations. ${ }^{49}$ While, in this study, we focus on U.S. born children, the ongoing debate underscores the questionable ethics behind family separations following immigration violations given the broadly acknowledged importance of keeping families together for the sake of children. Thus, further research addressing the many challenges faced by this population right now, as well as when they grow older, is warranted.

49 https://www.nytimes.com/2018/06/18/world/europe/trump-migrant-children-un.html 


\section{References}

Acosta, Y. D., Larse, L. J., \& Grieco, E. M. (2014). Noncitizens under age 35: 2010-2012. American Community Survey Briefs. Available at: https://www.census.gov/library/publications/2014/acs/acsbr12-06.html

Adda, J., Björklund, A., \& Holmlund, H. (2011). The role of mothers and fathers in providing skills : evidence from parental deaths. IZA Discussion Paper, (5425), 1-52.

Amato, P. R. (2005). The impact of family formation change on the cognitive, social, and emotional well-being of the next generation. The Future of Children, 15, 75-96.

Amuedo-Dorantes, C., Arenas-Arroyo, E., \& Sevilla, A. (2018). Immigration enforcement and economic resources of children with likely unauthorized parents. Journal of Public Economics, 158, 63-78.

Amuedo-Dorantes, C., \& Bansak, C. (2014). Employment verification mandates and the labor market outcomes of likely unauthorized and native workers. Contemporary Economic Policy, 32, 671-680.

Amuedo-Dorantes, C., \& Lopez, M. (2017). The hidden educational costs of intensified immigration enforcement. Southern Economic Journal, 84,120 -154.

Amuedo-Dorantes, C., \& Lopez, M. J. (2015). Falling through the cracks? grade retention and school dropout among children of likely unauthorized immigrants. American Economic Review: Papers \& Proceedings, 105, 598-603.

Baker, B., \& Rytin, N. (2013). Estimates of Unauthorized Immigrant Population Residing in the United States. Population Estimates Office of Immigration Statistics. Available at: https://www.dhs.gov/immigration-statistics/population-estimates/unauthorized-resident

Bartel, A. P. (1989). Where do the new U.S. immigrants live ?. Journal of Labor Economics, 7, 371-391.

Bezin, E., Verdier, T., \& Zenou, Y. (2018). Crime, broken families, and punishment. CEPR Discussion Paper, 13014.

Bitler, M., Gelbach, J., \& Hoynes, H. (2006). Welfare reform and children's living arrangements arrangements. Journal of Human Resources, 41, 1-27.

Bohn, S., \& Lofstrom, M. (2013). Employment effects of state legislation against the hiring of unauthorized immigrant workers. In D. Card \& S. Raphael (Eds.), Immigration, Poverty, and Socioeconomic Inequality. New York: Russell Sage Foundation.

Bohn, S., Lofstrom, M., \& Steven, R. (2014). Did the 2007 legal arizona workers act reduce the states unauthorized immigrants? The Review of Economics and Statistics, 96, 258269.

Bohn, S., \& Pugatch, T. (2013). U.S. Border enforcement and mexican immigrant location choice. demography, 52, 1543-1570.

Borjas, G. J. (2017). The labor supply of undocumented immigrants. Labour Economics, 46, 
$1-13$.

Brabeck, K., \& Qingwen Xu. (2010). The impact of detention and deportation on latino immigrant children and families: a quantitative exploration. Hispanic Journal of Behavioral Sciences, 32, 341-361.

Brooks-Gunn, J., Duncan, G. J., \& Maritato, N. (1997). Poor families, poor outcomes: the well-being of children and youth. In D. Duncan \& J. Brooks-Gunn (Eds.), Consequences of Growing Up Poor. New York: Russell Sage Foundation.

Capps, B. R., Koball, H., Bachmeier, J. D., Soto, A. G. R., Zong, J., \& Gelatt, J. (2016). Deferred action for unauthorized immigrants parents: analysis of dapa's potential effects on families and children. Migration Policy Institute and Urban Institute. Washington, D.C. Available at: https://www.migrationpolicy.org/research/deferred-actionunauthorized-immigrant-parents-analysis-dapas-potential-effects-families

Capps, R., Castaneda, R. M., Chaudry, A., \& Santos, R. (2007). Paying the price: the impact of immigration raids on america's children. The Urban Institute. Washington, DC. Available at: https://www.urban.org/research/publication/paying-price-impactimmigration-raids-americas-children

Card, D. (2001). Immigrant inflows, native outflows, and the local labor market impacts of higher immigration. Journal of Labor Economics, 19, 22-64.

Case, A., Lin, I.-F., \& McLanahan, S. (2000). How hungry is the selfish gene?. The Economic Journal, 110, 781-804.

Chaudry, A., Capps, R., Pedroza, J. M., Castaneda, R. M., Santos, R., Scott, M. M., \& Institute, U. (2010). Facing our future: children in the aftermath of immigration enforcement. Urban Institute. Available at: https://www.urban.org/research/publication/facing-our-future

Cortes, P., \& Tessada, J. (2011). Low-skilled immigration and the labor supply of highly skilled women. American Economic Journal: Applied Economics, 3, 88-123.

Delva, J., Horner, P., Martinez, R., Sanders, L., Lopez, W. D., \& Doering-White, J. (2013). Mental health problems of children of undocumented parents in the united states: a hidden crisis. Journal of Community Positive Practices, 13, 25-35.

Dreby, J. (2012). How today's immigration enforcement policies impact children, families, and communities: a view from the ground. Center for American Progress. Avialable at: https://www.americanprogress.org/issues/immigration/reports/2012/08/20/27082/howtodays-immigration-enforcement-policies-impact-children-families-and-communities/

Enchautegui, M. E., \& Menjivar, C. (2015). Paradoxes of family immigration policy: separation, reorganization, and reunification of families under current immigration laws. Law and Policy, 37, 32-60.

Fagan, J., \& Meares, T. (2008). Punishment, deterrence and social control: the paradox of punishment in minority communities. Ohio State Journal of Criminal Law, 6, 173-229.

Fagan, J., \& Tyler, T. R. (2008). Legitimacy, compliance and cooperation: procedural justice 
and citizen ties to the law. Ohio State Journal of Criminal Law, 6, 231-275.

Hagan, J., Castro, B., \& Rodriguez, N. (2010). The effects of u.s. deportation policies on immigrant families and communities: cross-border perspectives. North Carolina Law Review, 88, 1799-1824.

Hoynes, H., Miller, D. L., \& Schaller, J. (2012). Who suffers during recessions? Journal of Economic Perspectives, 26, 27-48.

Hoynes, H., \& Schanzenbach, D. W. (2012). Work incentives and the food stamp program. Journal of Public Economics, 96, 151-162.

Kostandini, G., Mykerezi, E., \& Escalante, C. (2013). The impact of immigration enforcement on the u.s. farming sector. American Journal of Agricultural Economics, 96, 172-192.

Legislatures, N. C. of S. (2017). State E-Verify laws. Retrieved January 1, 2017, from http://www.ncsl.org/research/immigration/everify-faq.aspx\#2012 State Action

McLanahan, S. (2004). Diverging destinies: how children are faring under the second demographic transition. Demography, 41, 607-627.

Menjivar, C. (2006). Liminal legality: salvadoran and guatemalan immigrants' lives in the United States. American Journal of Sociology, 111, 999-1037.

Murray, J., Farrington, D. P., \& Sekol, I. (2012). Children's antisocial behavior, mental health, drug use, and educational performance after parental incarceration: a systematic review and meta-analysis. Psychological Bulletin, 138, 175-210.

Nguyen, M. T., \& Gill, H. (2015). Interior immigration enforcement: the impacts of expanding local law enforcement authority. Urban Studies, 53, 302-323.

Orrenius, P. M., \& Zavodny, M. (2016). Do state work eligibility verification laws reduce unauthorized immigration? IZA Journal of Migration, 5, 5.

Passel, J. S., \& Cohn, D. V. (2009). A portrait of unauthorized immigrants in the united states. Pew Research Center. Available at: http://www.pewhispanic.org/2009/04/14/aportrait-of-unauthorized-immigrants-in-the-united-states/

Passel, J. S., Lopez, M. H., Cohn, D., \& Rohal, M. (2014). As growth stalls, unauthorized immigrant population becomes more settled. Pew Research Center. Available at: http://www.pewhispanic.org/2014/09/03/as-growth-stalls-unauthorized-immigrantpopulation-becomes-more-settled/

Pierce, S., \& Selee, A. (2017). Immigration under Trump: a review of policy shifts in the year since the election. Policy Brief, Migration Policy Institute. Available at: https://www.migrationpolicy.org/research/immigration-under-trump-review-policyshifts

Pope, N. G. (2016). The effects of DACAmentation: The impact of Deferred Action for Childhood Arrivals on unauthorized immigrants. Journal of Public Economics, 143, 98114. 
Ruggles, S., Genadek, K., Goeken, R., Grover, J., \& Sobek, M. (2017). Integrated public use microdata series: version 7.0 [dataset]. Minneapolis: University of Minnesota. Retrieved from https://doi.org/10.18128/D010.V7.0.

Skogan, W., \& Frydl, K. (2004). Fairness and effectiveness in policing: the evidence. W. Skogan \& K. Frydl, Eds. Washington, D.C: The National Academies Press.

Stock, J., \& Yogo, M. (2005). Testing for weak instruments in linear iv regression. In Identification and Inference for Econometric Models: Essays in Honor of Thomas Rothenberg (Andrew DWK, pp. 80-105). New York: Cambridge: Cambridge University Press.

Tyler, T. R. (2010). Legitimacy in corrections: policy implications. Criminology and Public Policy, 9, 127-134.

U.S. Immigration and Customs Enforcement (ICE). (2013). Fact sheet: delegation of immigration authority section 287(g) Immigration and Nationality Act. Available at: https://www.ice.gov/287g

U.S. Immigration and Customs Enforcement (ICE). (2017a). 100 Days of ICE. Retrieved July 20, 2005, from https://www.ice.gov/features/100-days

U.S. Immigration and Customs Enforcement (ICE). (2017b). Secure Communities. Retrieved January 1, 2017, from https://www.ice.gov/secure-communities\#tab1

Van Hook, J., Bachmeier, J. D., Coffman, D. L., \& Harel, O. (2015). Can we spin straw into gold? an evaluation of immigrant legal status imputation approaches. Demography, 52, 329-354.

Vaughan, J. M. (2013). Deportation Numbers Unwrapped Raw Statistics Reveal the Real Story of ICE Enforcement in Decline. Center for Immigration Studies. Available at: https://cis.org/Report/Deportation-Numbers-Unwrapped 
Table 1: Summary Statistics

\begin{tabular}{|c|c|c|}
\hline Descriptive Statistics: & Mean & S.D \\
\hline \multicolumn{3}{|c|}{ Panel A - First Outcome: Children's Likelihood of Living without their Parents } \\
\hline \multicolumn{3}{|c|}{ Probability of Living without parents: } \\
\hline Probability the Household Head is Likely Unauthorized & 0.076 & 0.265 \\
\hline Probability the Household Head is Naturalized & 0.095 & 0.293 \\
\hline Probability the Household Head is U.S. born & 0.180 & 0.384 \\
\hline Enforcement Index & 0.936 & 0.947 \\
\hline Enforcement Index using Historical Location & 0.076 & 0.130 \\
\hline Police-based enforcement & 0.832 & 0.769 \\
\hline Employment enforcement & 0.073 & 0.255 \\
\hline Child's Age & 7.310 & 4.440 \\
\hline Years of education of Household Head & 6.850 & 3.579 \\
\hline Years in the United States of Household Head & 18.177 & 7.899 \\
\hline State's Welfare Generosity & 0.552 & 0.497 \\
\hline State-wide Trust Act & 0.073 & 0.260 \\
\hline Observations & & 195,874 \\
\hline \multicolumn{3}{|c|}{ Panel B - Second Outcome: Children's Likelihood of Living with Married Moms with Absent Spouses } \\
\hline \multicolumn{3}{|c|}{ Probability of Living with a Mom whose Spouse is Absent: } \\
\hline Probability the Mother is Likely Unauthorized & 0.033 & 0.178 \\
\hline Probability the Mother is Naturalized & 0.052 & 0.223 \\
\hline Probability the Mother is U.S. born & 0.105 & 0.306 \\
\hline Enforcement Index & 1.008 & 0.943 \\
\hline Enforcement Index using Historical Location & 0.074 & 0.121 \\
\hline Police-based enforcement & 0.904 & 0.798 \\
\hline Employment enforcement & 0.099 & 0.292 \\
\hline Child's Age & 7.772 & 4.357 \\
\hline Years of education of the Mother & 6.913 & 3.354 \\
\hline Years in the United States of the Mother & 15.606 & 6.394 \\
\hline State's Welfare Generosity & 0.550 & 0.497 \\
\hline State-wide Trust Act & 0.071 & 0.257 \\
\hline Observations & & 91,828 \\
\hline
\end{tabular}

Notes: Samples: In Panel A, our sample consists of Hispanic, U.S. born children ages 0-15 residing in households headed by a low skill (with less than a high school diploma) and long-term Hispanic resident (with 5+ years of residency in the United States). In Panel B, the sample is U.S. born children ages 0-15 residing with their married, Hispanic, low-skill and long-term resident mom. 
Table 2: Probability of Living without Their Parents

\begin{tabular}{|c|c|c|c|c|c|c|c|c|c|c|c|c|}
\hline \multirow{2}{*}{$\begin{array}{l}\text { Panel: } \\
\text { Model Specification: }\end{array}$} & \multicolumn{4}{|c|}{ Panel A: Likely Undocumented HH Head } & \multicolumn{4}{|c|}{ Panel B: Naturalized HH Head } & \multicolumn{4}{|c|}{ Panel C: U.S. Born HH Head } \\
\hline & (1) & (2) & (3) & (4) & (1) & (2) & (3) & (4) & (1) & (2) & (3) & (4) \\
\hline Enforcement Index & $\begin{array}{c}0.002 \\
(0.002)\end{array}$ & $\begin{array}{c}0.001 \\
(0.002)\end{array}$ & $\begin{array}{c}0.001 \\
(0.002)\end{array}$ & $\begin{array}{c}0.001 \\
(0.002)\end{array}$ & $\begin{array}{c}0.006 \\
(0.005)\end{array}$ & $\begin{array}{c}0.010 \\
(0.007)\end{array}$ & $\begin{array}{l}0.013 * \\
(0.008)\end{array}$ & $\begin{array}{c}0.019 * * \\
(0.009)\end{array}$ & $\begin{array}{c}0.005 \\
(0.007)\end{array}$ & $\begin{array}{l}-0.004 \\
(0.006)\end{array}$ & $\begin{array}{l}-0.002 \\
(0.007)\end{array}$ & $\begin{array}{l}-0.008 \\
(0.010)\end{array}$ \\
\hline Individual Characteristics & Yes & Yes & Yes & Yes & Yes & Yes & Yes & Yes & Yes & Yes & Yes & Yes \\
\hline State-wide Trust Act & No & No & Yes & Yes & No & No & Yes & Yes & No & No & Yes & Yes \\
\hline State's Welfare Generosity & No & No & Yes & Yes & No & No & Yes & Yes & No & No & Yes & Yes \\
\hline Pre-treatment Characteristics & No & No & Yes & No & No & No & Yes & No & No & No & Yes & No \\
\hline Years FE & No & Yes & Yes & Yes & No & Yes & Yes & Yes & No & Yes & Yes & Yes \\
\hline MSA FE & No & Yes & Yes & Yes & No & Yes & Yes & Yes & No & Yes & Yes & Yes \\
\hline MSA-trends & No & No & No & Yes & No & No & No & Yes & No & No & No & Yes \\
\hline Observations & 131,100 & 131,100 & 131,100 & 131,100 & 43,079 & 43,079 & 43,079 & 43,079 & 34,005 & 34,005 & 34,005 & 34,005 \\
\hline R-squared & 0.029 & 0.038 & 0.038 & 0.042 & 0.052 & 0.071 & 0.070 & 0.077 & 0.052 & 0.082 & 0.080 & 0.090 \\
\hline Dependent Variable Mean & \multicolumn{4}{|c|}{0.076} & \multicolumn{4}{|c|}{0.095} & \multicolumn{4}{|c|}{0.18} \\
\hline
\end{tabular}

Notes: Sample: U.S. born Hispanic children ages 0-15 residing in households headed by a low skill (with less than a high school diploma) and long-term Hispanic resident (with 5+ years of residency in the United States). We distinguish according to whether the HH Head is a likely undocumented immigrant, a naturalized immigrant or U.S. born. Model specifications: All model specifications include a constant term. In addition, specification (1) includes the following individual characteristics: the child's age, years of education and years living in the United States of the household head. Specification (2) includes area and time fixed effects. Specification (3) adds welfare generosity at the state level, state-level Trust Acts, and the following characteristics measured in the year 2000 and interacted with a time trend: MSA unemployment rates, the share of Hispanics in the MSA, and the share of people voting republican in the state. Specification (4) further adds the MSA-specific time trend as in equation (3) in the text. Standard errors are in parentheses and are clustered at the MSA level. $* * * p<0.01$, $* * \mathrm{p}<0.05, * \mathrm{p}<0.1$. 
Table 3: Probability of Living with Married Moms with Absent Spouses

\begin{tabular}{|c|c|c|c|c|c|c|c|c|c|c|c|c|}
\hline \multirow{2}{*}{$\begin{array}{l}\text { Panel: } \\
\text { Model Specification: }\end{array}$} & \multicolumn{3}{|c|}{ Panel A: Likely Undocumented } & \multirow{2}{*}{$\begin{array}{c}\text { Mother } \\
(4) \\
\end{array}$} & \multicolumn{4}{|c|}{ Panel B: Naturalized HH Mother } & \multicolumn{4}{|c|}{ Panel C: U.S. Born Mothers } \\
\hline & (1) & $(2)$ & (3) & & (1) & $(2)$ & (3) & (4) & (1) & $(2)$ & (3) & (4) \\
\hline Enforcement Index & $\begin{array}{c}0.001 \\
(0.002)\end{array}$ & $\begin{array}{l}0.005 * \\
(0.003)\end{array}$ & $\begin{array}{c}0.005 * * \\
(0.003)\end{array}$ & $\begin{array}{c}0.007 * * \\
(0.003)\end{array}$ & $\begin{array}{l}-0.006 \\
(0.006)\end{array}$ & $\begin{array}{l}-0.007 \\
(0.008)\end{array}$ & $\begin{array}{l}-0.010 \\
(0.009)\end{array}$ & $\begin{array}{l}-0.001 \\
(0.011)\end{array}$ & $\begin{array}{l}-0.007 \\
(0.006)\end{array}$ & $\begin{array}{l}-0.007 \\
(0.006)\end{array}$ & $\begin{array}{l}-0.009 \\
(0.006)\end{array}$ & $\begin{array}{l}-0.015 \\
(0.011)\end{array}$ \\
\hline Individual Characteristics & Yes & Yes & Yes & Yes & Yes & Yes & Yes & Yes & Yes & Yes & Yes & Yes \\
\hline State-wide Trust Act & No & No & Yes & Yes & No & No & Yes & Yes & No & No & Yes & Yes \\
\hline State's Welfare Generosity & No & No & Yes & Yes & No & No & Yes & Yes & No & No & Yes & Yes \\
\hline Pre-treatment Characteristics & No & No & Yes & No & No & No & Yes & No & No & No & Yes & No \\
\hline Years FE & No & Yes & Yes & Yes & No & Yes & Yes & Yes & No & Yes & Yes & Yes \\
\hline MSA FE & No & Yes & Yes & Yes & No & Yes & Yes & Yes & No & Yes & Yes & Yes \\
\hline MSA-trends & No & No & No & Yes & No & No & No & Yes & No & No & No & Yes \\
\hline Observations & 91,828 & 91,828 & 91,828 & 91,828 & 15,351 & 15,351 & 15,351 & 15,351 & 18,130 & 18,130 & 18,130 & 18,130 \\
\hline R-squared & 0.000 & 0.014 & 0.014 & 0.021 & 0.001 & 0.050 & 0.052 & 0.069 & 0.003 & 0.066 & 0.064 & 0.087 \\
\hline Dependent Variable Mean & \multicolumn{4}{|c|}{0.033} & \multicolumn{4}{|c|}{0.052} & \multicolumn{4}{|c|}{0.104} \\
\hline
\end{tabular}

Notes: Sample: U.S. born Hispanic children ages 0-15 residing with their married, Hispanic, low-skill and long-term resident moms. We distinguish according to whether the mother is likely undocumented, naturalized or U.S. born. Model specifications: All model specifications include a constant term. In addition, specification (1) includes the following individual characteristics: the child's age, years of education and years living in the United States of the household head. Specification (2) includes area and time fixed effects. Specification (3) adds welfare generosity at the state level, state-level Trust Acts, and the following characteristics measured in the year 2000 and interacted with a time trend: MSA unemployment rates, the share of Hispanics in the MSA, and the share of people voting republican in the state. Specification (4) further adds the MSA-specific time trend as in equation (3) in the text. Standard errors are in parentheses and are clustered at the MSA level. $* * * \mathrm{p}<0.01, * * \mathrm{p}<0.05, * \mathrm{p}<0.1$ 
Table 4: Robustness Check \#1 Falsification Test: Probability of Living Arrangement of White Non-Hispanic Children

\begin{tabular}{|c|c|c|c|c|c|c|}
\hline \multirow{2}{*}{$\begin{array}{l}\text { Outcome: } \\
\text { Panel: }\end{array}$} & \multicolumn{3}{|c|}{ Probability of Living without Their Parents } & \multicolumn{3}{|c|}{ Probability of Living with Married Moms with Absent Spouses } \\
\hline & $\begin{array}{c}\text { Panel A: Likely } \\
\text { Undocumented } \\
\text { HH Head }\end{array}$ & $\begin{array}{c}\text { Panel B: } \\
\text { Naturalized } \\
\text { HH Head } \\
\end{array}$ & $\begin{array}{l}\text { Panel C: } \\
\text { U.S. Born } \\
\text { HH Head } \\
\end{array}$ & $\begin{array}{c}\text { Panel A: Likely } \\
\text { Undocumented } \\
\text { Mother }\end{array}$ & $\begin{array}{c}\text { Panel B: } \\
\text { Naturalized } \\
\text { Mother } \\
\end{array}$ & $\begin{array}{c}\text { Panel C: } \\
\text { U.S. Born Mothers }\end{array}$ \\
\hline Enforcement Index & $\begin{array}{c}0.067 \\
(0.045)\end{array}$ & $\begin{array}{c}0.053 \\
(0.064)\end{array}$ & $\begin{array}{c}-0.007 \\
(0.006)\end{array}$ & $\begin{array}{c}0.016 \\
(0.020)\end{array}$ & $\begin{array}{c}0.032 \\
(0.043)\end{array}$ & $\begin{array}{c}0.001 \\
(0.001)\end{array}$ \\
\hline Individual Characteristics & Yes & Yes & Yes & Yes & Yes & Yes \\
\hline State-wide Trust Act & Yes & Yes & Yes & Yes & Yes & Yes \\
\hline State's Welfare Generosity & Yes & Yes & Yes & Yes & Yes & Yes \\
\hline Pre-treatment Characteristics & No & No & No & No & No & No \\
\hline Years FE & Yes & Yes & Yes & Yes & Yes & Yes \\
\hline MSA FE & Yes & Yes & Yes & Yes & Yes & Yes \\
\hline MSA-trends & Yes & Yes & Yes & Yes & Yes & Yes \\
\hline Observations & 1,183 & 696 & 69,509 & 1,919 & 1,437 & 343,159 \\
\hline R-squared & 0.359 & 0.395 & 0.049 & 0.200 & 0.526 & 0.012 \\
\hline Dependent Variable Mean & 0.03 & 0.02 & 0.01 & 0.10 & 0.13 & 0.12 \\
\hline
\end{tabular}

Notes: Samples: Outcome \#1: White non-Hispanic U.S. born children ages 0-15 residing in households headed by a low skilled (with less than a high school diploma) and long-term U.S. resident (with 5+ years of residency in the United States). Outcome \#2: White non-Hispanic U.S. born children ages 0-15 residing with their married, low-skill mom. Model specifications: All model specifications include a constant term, as well as the controls in specification (4) in Tables 2 and 3. Standard errors are in parentheses and are clustered at the MSA level. $* * * \mathrm{p}<0.01, * * \mathrm{p}<0.05, * \mathrm{p}<0.1$. 
Table 5: Robustness Check \#2

Immigration Enforcement and Children's Living Arrangement

\begin{tabular}{|c|c|c|}
\hline Column & (1) & $(2)$ \\
\hline Outcome: & $\begin{array}{l}\text { Probability of Living } \\
\text { Without Their Parents }\end{array}$ & $\begin{array}{c}\text { Probability of Living with Married } \\
\text { Moms with Absent Spouses } \\
\end{array}$ \\
\hline HH Head/Mother: & Naturalized HH Head & Likely Undocumented Mother \\
\hline \multicolumn{3}{|c|}{ Panel A: Using an Alternative Definition of Likely Undocumented Parents } \\
\hline Enforcement Index & $\begin{array}{l}0.024 * * \\
(0.011)\end{array}$ & $\begin{array}{l}0.004 * \\
(0.002)\end{array}$ \\
\hline Individual Characteristics & Yes & Yes \\
\hline State-wide Trust Act & Yes & Yes \\
\hline State's Welfare Generosity & Yes & Yes \\
\hline Years FE & Yes & Yes \\
\hline MSA FE & Yes & Yes \\
\hline MSA-trends & Yes & Yes \\
\hline Observations & 26,914 & 118,852 \\
\hline R-squared & 0.118 & 0.025 \\
\hline Mean Dependent Variable & 0.08 & 0.027 \\
\hline \multicolumn{3}{|c|}{ Panel B: Excluding Maricopa County } \\
\hline Enforcement Index & $\begin{array}{c}0.023 * * \\
(0.009)\end{array}$ & $\begin{array}{l}0.008 * \\
(0.004)\end{array}$ \\
\hline Individual Characteristics & Yes & Yes \\
\hline State-wide Trust Act & Yes & Yes \\
\hline State's Welfare Generosity & Yes & Yes \\
\hline Years FE & Yes & Yes \\
\hline MSA FE & Yes & Yes \\
\hline MSA-trends & Yes & Yes \\
\hline Observations & 41,922 & 88,596 \\
\hline R-squared & 0.077 & 0.022 \\
\hline Mean Dependent Variable & 0.095 & 0.032 \\
\hline \multicolumn{3}{|c|}{ Panel C: Including Non-Citizen Children in the Sample } \\
\hline Enforcement Index & $\begin{array}{c}0.013 * * \\
(0.005)\end{array}$ & $\begin{array}{c}0.008 * * \\
(0.003)\end{array}$ \\
\hline Individual Characteristics & Yes & Yes \\
\hline State-wide Trust Act & Yes & Yes \\
\hline State's Welfare Generosity & Yes & Yes \\
\hline Years FE & Yes & Yes \\
\hline MSA FE & Yes & Yes \\
\hline MSA-trends & Yes & Yes \\
\hline Observations & 47,146 & 106,065 \\
\hline R-squared & 0.079 & 0.021 \\
\hline Mean Dependent Variable & 0.06 & 0.04 \\
\hline
\end{tabular}

Notes: Samples: Outcome \#1: U.S. born Hispanic children ages 0-15 residing in households headed by a low skill (with less than a high school diploma) and naturalized Hispanic resident (with 5+ years of residency in the United States). Outcome \#2: U.S. born Hispanic children ages 0-15 residing with their married likely undocumented moms. Model specifications: All model specifications include a constant term, as well as the controls in specification (4) in Tables 2 and 3. Standard errors are in parentheses and are clustered at the MSA level. $* * * \mathrm{p}<0.01, * * \mathrm{p}<0.05, * \mathrm{p}<0.1$ 
Table 6: Identification Check \#1

Testing for the Parallel Trends Assumption

\begin{tabular}{|c|c|c|}
\hline Panel: & Panel A & $\begin{array}{c}\text { Panel B } \\
\end{array}$ \\
\hline Outcome: & $\begin{array}{l}\text { Probability of Living } \\
\text { Without Their Parents }\end{array}$ & $\begin{array}{l}\text { Probability of Living with Married Moms } \\
\text { with Absent Spouses }\end{array}$ \\
\hline HH Head/Mother: & Naturalized HH Head & Likely Undocumented Mother \\
\hline \multicolumn{3}{|l|}{ Years Prior to the EI>0: } \\
\hline 1 Year Prior & $\begin{array}{l}-0.006 \\
(0.009)\end{array}$ & $\begin{array}{c}0.005 \\
(0.006)\end{array}$ \\
\hline 2 Years Prior & $\begin{array}{l}-0.002 \\
(0.012)\end{array}$ & $\begin{array}{c}0.000 \\
(0.006)\end{array}$ \\
\hline 3 Years Prior & $\begin{array}{c}0.001 \\
(0.010)\end{array}$ & $\begin{array}{c}0.006 \\
(0.010)\end{array}$ \\
\hline 4 Years Prior & $\begin{array}{c}0.011 \\
(0.015)\end{array}$ & $\begin{array}{c}0.003 \\
(0.009)\end{array}$ \\
\hline 5 Years Prior & $\begin{array}{l}-0.006 \\
(0.009)\end{array}$ & $\begin{array}{l}-0.001 \\
(0.013)\end{array}$ \\
\hline 6 Years Prior & $\begin{array}{l}-0.002 \\
(0.012)\end{array}$ & $\begin{array}{l}-0.017 \\
(0.017)\end{array}$ \\
\hline Enforcement Index & $\begin{array}{l}0.015 * \\
(0.008)\end{array}$ & $\begin{array}{c}0.006 * * \\
(0.003)\end{array}$ \\
\hline $\begin{array}{l}\text { Individual Characteristics } \\
\text { State-wide Trust Act } \\
\text { State's Welfare Generosity } \\
\text { Years FE } \\
\text { MSA FE } \\
\text { MSA-trends }\end{array}$ & $\begin{array}{l}\text { Yes } \\
\text { Yes } \\
\text { Yes } \\
\text { Yes } \\
\text { Yes } \\
\text { Yes }\end{array}$ & $\begin{array}{l}\text { Yes } \\
\text { Yes } \\
\text { Yes } \\
\text { Yes } \\
\text { Yes } \\
\text { Yes }\end{array}$ \\
\hline $\begin{array}{l}\text { Observations } \\
\text { R-squared }\end{array}$ & $\begin{array}{c}43,079 \\
0.072\end{array}$ & $\begin{array}{c}91,828 \\
0.017\end{array}$ \\
\hline Dependent Variable Mean & 0.095 & 0.033 \\
\hline
\end{tabular}

Notes: Samples: Outcome \#1: U.S. born Hispanic children ages 0-15 residing in households headed by a low skill (with less than a high school diploma) and naturalized Hispanic resident (with 5+ years of residency in the United States). Outcome \#2: U.S. born Hispanic children ages 0-15 residing with their married likely undocumented moms. Model specifications: All model specifications include a constant term, as well as the controls in specification (4) in Tables 2 and 3. Standard errors are in parentheses and are clustered at the MSA level. $* * * \mathrm{p}<0.01, * * \mathrm{p}<0.05, * \mathrm{p}<0.1$. 
Table 7: Identification Check \#2

Assessing the Endogenous Adoption of Immigration Enforcement

\begin{tabular}{|c|c|c|}
\hline \multicolumn{3}{|c|}{ Part 1 - Assessing the Endogeneity of the Adoption Timing } \\
\hline Panel: & Panel A & Panel B \\
\hline Outcome: & First Year IE>0 & First Year IE >0 \\
\hline HH Head/Mother: & Naturalized HH Head & Likely Undocumented Mother \\
\hline $\begin{array}{l}\text { Average Share of Children in MSA Living } \\
\text { without Their Parents }\end{array}$ & $\begin{array}{c}0.077 \\
(0.116)\end{array}$ & \\
\hline $\begin{array}{l}\text { Average Share of Children in MSA Living } \\
\text { with a Mom whose Spouse is Absent }\end{array}$ & & $\begin{array}{l}-0.163 \\
(0.397)\end{array}$ \\
\hline $\begin{array}{l}\text { Collapsed Individual Characteristics } \\
\text { Collapsed Area Characteristics } \\
\text { State FE }\end{array}$ & $\begin{array}{l}\text { Yes } \\
\text { Yes } \\
\text { Yes }\end{array}$ & $\begin{array}{l}\text { Yes } \\
\text { Yes } \\
\text { Yes }\end{array}$ \\
\hline $\begin{array}{l}\text { Observations } \\
\text { R-squared }\end{array}$ & $\begin{array}{c}118 \\
0.783\end{array}$ & $\begin{array}{c}133 \\
0.806\end{array}$ \\
\hline \multicolumn{3}{|l|}{ Part 2-Assessing the Endogeneity of the IE } \\
\hline Panel: & Panel A & Panel B \\
\hline Outcome: & EI Value First Year IE>0 & EI Value First Year IE>0 \\
\hline HH Head/Mother: & Naturalized HH Head & Likely Undocumented Mother \\
\hline $\begin{array}{l}\text { Average Share of Children in MSA Living } \\
\text { without Their Parents }\end{array}$ & $\begin{array}{c}0.001 \\
(0.114)\end{array}$ & \\
\hline $\begin{array}{l}\text { Average Share of Children in MSA Living } \\
\text { with a Mom whose Spouse is Absent }\end{array}$ & & $\begin{array}{l}-0.097 \\
(0.300)\end{array}$ \\
\hline Collapsed Individual Characteristics & Yes & Yes \\
\hline Collapsed Area Characteristics & Yes & Yes \\
\hline State FE & Yes & Yes \\
\hline Observations & 118 & 133 \\
\hline R-squared & 0.55 & 0.415 \\
\hline
\end{tabular}

Notes: Sample: ALL MSAs in the samples used in Table 2, Panel B, and in Table 3, Panel A. The Collapsed Individual Characteristics include: the average age of Hispanic children, the average education level of the $\mathrm{HH}$ head, and the average number of years in the United States of household head or mother. The Collapsed Area Characteristics include: the share voting Republican, average unemployment rate, the share of undocumented immigrants, and the share of children receiving TANF. Robust standard errors are in parentheses and clustered at the state level. $* * * \mathrm{p}<0.01, * * \mathrm{p}<0.05, * \mathrm{p}<0.1$ 
Table 8: Identification Check \#3

Addressing the Non-random Location of Immigrants

\begin{tabular}{|c|c|c|}
\hline Panel: & Panel A & Panel B \\
\hline Outcome: & $\begin{array}{c}\text { Probability of Living } \\
\text { Without Their Parents }\end{array}$ & $\begin{array}{c}\text { Probability of Living with Married } \\
\text { Moms with Absent Spouses }\end{array}$ \\
\hline HH Head/Mother: & $\begin{array}{c}\text { Naturalized HH Head with Likely } \\
\text { Undocumented Household Members }\end{array}$ & $\begin{array}{c}\text { Likely Undocumented } \\
\text { Mother } \\
\end{array}$ \\
\hline Enforcement Index & $\begin{array}{c}0.036 * * \\
(0.018)\end{array}$ & $\begin{array}{c}0.018 * * \\
(0.008)\end{array}$ \\
\hline $\begin{array}{l}\text { Individual Characteristics } \\
\text { State-wide Trust Act } \\
\text { State's Welfare Generosity } \\
\text { Years FE } \\
\text { MSA FE } \\
\text { MSA-trends }\end{array}$ & $\begin{array}{l}\text { Yes } \\
\text { Yes } \\
\text { Yes } \\
\text { Yes } \\
\text { Yes } \\
\text { Yes }\end{array}$ & $\begin{array}{l}\text { Yes } \\
\text { Yes } \\
\text { Yes } \\
\text { Yes } \\
\text { Yes } \\
\text { Yes }\end{array}$ \\
\hline $\begin{array}{l}\text { Observations } \\
\text { R-squared }\end{array}$ & $\begin{array}{c}25,844 \\
0.058\end{array}$ & $\begin{array}{c}91,828 \\
0.021\end{array}$ \\
\hline \multicolumn{3}{|l|}{ First Stage Results } \\
\hline IV & $\begin{array}{l}8.02 * * * \\
(1.655)\end{array}$ & $\begin{array}{l}3.473 * * * \\
(1.286)\end{array}$ \\
\hline $\begin{array}{l}\text { R-squared } \\
\text { F-statistic }\end{array}$ & $\begin{array}{c}0.80 \\
23.49\end{array}$ & $\begin{array}{l}0.886 \\
35.55\end{array}$ \\
\hline Dependent Variable Mean & 0.12 & 0.033 \\
\hline
\end{tabular}

Notes: Samples: Outcome \#1: U.S. born Hispanic children ages 0-15 residing in households headed by a low skill (with less than a high school diploma) and naturalized Hispanic resident (with 5+ years of residency in the United States) with likely undocumented household members. Outcome \#2: U.S. born Hispanic children ages 0-15 residing with their married likely undocumented moms. Model specifications: All model specifications include a constant term, as well as the controls in specification (4) in Tables 2 and 3. Standard errors are in parentheses and are clustered at the MSA level. $* * * \mathrm{p}<0.01, * * \mathrm{p}<0.05, * \mathrm{p}<0.1$. 
Table 9: Channels for the Observed Impacts \#1

Probability of Living Arrangement by Type of Immigration Enforcement

\begin{tabular}{lcc}
\hline Panel: & Panel A & Panel B \\
\hline Outcome: & $\begin{array}{c}\text { Probability of Living } \\
\text { Without Their Parents }\end{array}$ & $\begin{array}{c}\text { Probability of Living with Married } \\
\text { Moms with Absent Spouses }\end{array}$ \\
\hline HH Head/Mother: & Naturalized HH Head & Likely Undocumented Mother \\
\hline Police Based Enforcement & $\mathbf{0 . 0 1 9 * *}$ & $\mathbf{0 . 0 1 1 * *}$ \\
& $\mathbf{( 0 . 0 0 9 )}$ & $\mathbf{( 0 . 0 0 5 )}$ \\
Employment Enforcement & 0.024 & -0.003 \\
& $(0.023)$ & $(0.008)$ \\
Individual Characteristics & Yes & Yes \\
State-wide Trust Act & Yes & Yes \\
State's Welfare Generosity & Yes & Yes \\
Years FE & Yes & Yes \\
MSA FE & Yes & Yes \\
MSA-trends & Yes & Yes \\
Observations & 39,845 & 91,828 \\
R-squared & 0.080 & 0.023 \\
Dependent Variable Mean & 0.095 & 0.033 \\
\hline
\end{tabular}

Notes: Samples: Outcome \#1: U.S. born Hispanic children ages 0-15 residing in households headed by a low skill (with less than a high school diploma) and naturalized Hispanic resident (with 5+ years of residency in the United States). Outcome \#2: U.S. born Hispanic children ages 0-15 residing with their married likely undocumented moms. Model specifications: All model specifications include a constant term, as well as the controls in specification (4) in Tables 2 and 3. Standard errors are in parentheses and are clustered at the MSA level. $* * * \mathrm{p}<0.01, * * \mathrm{p}<0.05, * \mathrm{p}<0.1$. 
Table 10: Channels for the Observed Impacts \#2

Probability of Living Arrangement by Type of Immigration Enforcement

\begin{tabular}{lcc}
\hline Panel: & Panel A & Panel B \\
Outcome: & $\begin{array}{c}\text { Probability of Living } \\
\text { without Their Parents }\end{array}$ & $\begin{array}{c}\text { Probability of Living with Married } \\
\text { Moms with Absent Spouses }\end{array}$ \\
\hline HH Head/Mother: & Naturalized HH Head & Likely Undocumented Mother \\
\hline Secure Communities & $\mathbf{0 . 0 3 2 * *}$ & 0.011 \\
& $\mathbf{( 0 . 0 1 4 )}$ & $(0.010)$ \\
E-verify & 0.006 & -0.004 \\
& $(0.016)$ & $(0.010)$ \\
OIL mandates & -0.038 & 0.000 \\
& $(0.027)$ & $(0.019)$ \\
Local 287g & -0.009 & $\mathbf{0 . 0 1 3} * *$ \\
& $(0.010)$ & $\mathbf{( 0 . 0 0 6 )}$ \\
State 287g & 0.025 & 0.011 \\
& $(0.024)$ & $(0.010)$ \\
Individual Characteristics & Yes & Yes \\
State-wide Trust Act & Yes & Yes \\
State's Welfare Generosity & Yes & Yes \\
Years FE & Yes & Yes \\
MSA FE & Yes & Yes \\
MSA-trends & Yes & Yes \\
Observations & 43,079 & 91,828 \\
R-squared & 0.077 & 0.023 \\
Dependent Variable Mean & 0.095 & 0.033 \\
\hline
\end{tabular}

Notes: Samples: Outcome \#1: U.S. born Hispanic children ages 0-15 residing in households headed by a low skill (with less than a high school diploma) and naturalized Hispanic resident (with 5+ years of residency in the United States). Outcome \#2: U.S. born Hispanic children ages 0-15 residing with their married likely undocumented moms. Model specifications: All model specifications include a constant term, as well as the controls in specification no. 4 in Tables 2 and 3. Standard errors are in parentheses and are clustered at the MSA level. $* * * \mathrm{p}<0.01, * * \mathrm{p}<0.05, * \mathrm{p}<0.1$ 